\title{
Applicability of Nonaqueous Electrolytes for Electrolytic Extraction of Inclusion Particles Containing Zr, Ti, and Ce
}

\author{
Ryo INOUE, ${ }^{1) *}$ Rika KIMURA, ${ }^{1)}$ Shigeru UEDA ${ }^{1)}$ and Hideaki SUITO ${ }^{21}$ \\ 1) Institute of Multidisciplinary Research for Advanced Materials, Tohoku University, Sendai, 980-8577 Japan. \\ 2) Professor Emeritus, Tohoku University, Sendai, 980-8577 Japan.
}

(Received on July 16, 2013; accepted on September 12, 2013)

\begin{abstract}
The estimation of fine inclusion particles is required in order to clarify its effect on the miniaturization of steel grain. In this study, the stability of $\mathrm{ZrO}_{2}, \mathrm{Ti}_{2} \mathrm{O}_{3}, \mathrm{TiAl}_{2} \mathrm{O}_{5}, \mathrm{Ce}_{2} \mathrm{O}_{3}$, and $\mathrm{CeS}$ particles during extraction was examined using acid, halogen-methanol, and nonaqueous electrolytes. $\mathrm{ZrO}_{2}, \mathrm{Ti}_{2} \mathrm{O}_{3}$, and $\mathrm{TiAl}_{2} \mathrm{O}_{5}$ particles hardly dissolved in $4 \% \mathrm{MS}$ (4 v/v\% methylsalicylate-1 $\mathrm{w} / \mathrm{v} \%$ tetramethylammonium chloride-methanol) and $10 \%$ AA (10 v/v\% acetylacetones-1 w/v\% tetramethylammonium chloride-methanol) electrolytes, while $\mathrm{Ce}_{2} \mathrm{O}_{3}$ and $\mathrm{CeS}$ particles did not dissolve in a $2 \%$ TEA-Ba (2 v/v\% triethanolamine-1 w/v\% tetramethylammonium chloride-methanol containing $0.16-0.24 \mathrm{w} / \mathrm{v} \% \mathrm{Ba}$ ) electrolyte during potentiostatic extraction. The $\mathrm{O}$ content of the extracted $\mathrm{ZrO}_{2}, \mathrm{Ti}_{2} \mathrm{O}_{3}$, and $\mathrm{Ce}_{2} \mathrm{O}_{3}$ inclusion particles agreed approximately with the difference between analyzed total $\mathrm{O}$ content and calculated equilibrium $\mathrm{O}$ content of the metal, and the $\mathrm{S}$ content of the extracted CeS inclusion particles agreed with the analyzed total S content of the metal. The Ce content of the extracted inclusion particles was in agreement with that calculated using the results of two-dimensional measurements.
\end{abstract}

KEY WORDS: nonmetallic inclusion; $\mathrm{ZrO}_{2} ; \mathrm{Ti}_{2} \mathrm{O}_{3} ; \mathrm{TiAl}_{2} \mathrm{O}_{5} ; \mathrm{Ce}_{2} \mathrm{O}_{3} ; \mathrm{CeS}$; electrolytic extraction; nonaqueous electrolyte.

\section{Introduction}

It is well known that nonmetallic inclusion particles in steel compromise the mechanical property and corrosion resistance. Therefore, the removal and modification of these particles have been an important mission in the refining stage of the steelmaking process. The various methods recommended were proposed by the joint research studies ${ }^{1,2)}$ on quantitative analysis of nonmetallic inclusions. The inclusion particles concerned have grown to include complex multi-component systems, which sometimes contain chemically unstable components, after the modification of nonmetallic inclusion particles. ${ }^{3-6}$ An extraction method of the inclusion particles in steel, which can disregard the dissolution loss of inclusion particles during chemical treatment, is necessary in order to directly observe the size, morphology and number of inclusion particles and the elemental segregation in each particle.

Among chemical extraction methods, the electrolytic method using a nonaqueous electrolyte such as $4 \% \mathrm{MS}$ ( $4 \mathrm{v} / \mathrm{v} \%$ methylsalicylate $-1 \mathrm{w} / \mathrm{v} \%$ tetramethylammonium chloridemethanol), 2\%TEA ( $2 \mathrm{v} / \mathrm{v} \%$ triethanolamine $-1 \mathrm{w} / \mathrm{v} \%$ tetramethylammonium chloride (or $\mathrm{LiCl}$ )-methanol), or $10 \% \mathrm{AA}$ $(10 \mathrm{v} / \mathrm{v} \%$ acetylacetones $-1 \mathrm{w} / \mathrm{v} \%$ tetramethylammonium chloride-methanol) was expected to extract nonmetallic inclusion particles from steel with good quantitative reproducibility. However, it should be noted that some kinds of

* Corresponding author: E-mail: ryo@tagen.tohoku.ac.jp DOI: http://dx.doi.org/10.2355/isijinternational.53.1906 fine inclusion particles are dissolved during the electrolytic extraction process using conventional nonaqueous electrolysis. For this reason, the dissolution of $\mathrm{Al}_{2} \mathrm{O}_{3},{ }^{7)} \mathrm{TiO}_{x},{ }^{8)}$ nitrides,$\left.{ }^{9}\right)$ carbides, ${ }^{10,11)}$ carbonitride, ${ }^{9)}$ and sulfides ${ }^{12)}$ in the electrolytic solution was examined. In an earlier paper, ${ }^{13)}$ we reported that the chemically unstable $\mathrm{MgO}$ and $\mathrm{MgO} \cdot \mathrm{Al}_{2} \mathrm{O}_{3}$ inclusion particles could be extracted by the electrolytic method using a 2\%TEA electrolyte dehydrated with barium metal.

On the other hand, since the capacity of conventional electrolytes to dissolve iron is low, the amount of iron dissolved by electrolysis is insufficient; that is, the amount of inclusion particles extracted might not be enough for an analysis of their representative characteristics. In order to obtain many inclusion particles to ensure successful characterization, the dissolution of a large amount of steel is required. Chino et al. ${ }^{14)}$ reported that the iron weight dissolved by $40 \% \mathrm{MA}(40 \mathrm{w} / \mathrm{v} \%$ maleic anhydride- $3 \mathrm{w} / \mathrm{v} \%$ tetramethylammonium chloride-methanol) was 30 times more than that by conventional electrolytes.

In the present study, the applicability of nonaqueous electrolytes was investigated for the electrolytic extraction of $\mathrm{ZrO}_{2}, \mathrm{Ti}_{2} \mathrm{O}_{3}, \mathrm{TiAl}_{2} \mathrm{O}_{5}, \mathrm{Ce}_{2} \mathrm{O}_{3}$, and $\mathrm{CeS}$ inclusion particles from steel. For comparison, the extraction of $\mathrm{Al}_{2} \mathrm{O}_{3}$, which is considered chemically stable, was also examined.

\section{Experimental}

\subsection{Dissolution of Particles in Solution}

According to SEM observations, the average particle siz- 
es of $\mathrm{ZrO}_{2}, \mathrm{Ti}_{2} \mathrm{O}_{3}, \mathrm{CeO}_{2}$, and $\mathrm{Al}_{2} \mathrm{O}_{3}$ reagents (99.9\% purity) were $0.064,0.41,2.4$, and $0.24 \mu \mathrm{m}$, respectively. The $\mathrm{Ce}_{2} \mathrm{O}_{3}$ reagent was crushed in a mortar to a particle size of $1-6 \mu \mathrm{m}$ (average size: $2.0 \mu \mathrm{m}$ ). $\mathrm{TiAl}_{2} \mathrm{O}_{5}$ powder was prepared by sintering a stoichiometric mixture of $\mathrm{TiO}_{2}$ and $\mathrm{Al}_{2} \mathrm{O}_{3}$ reagents at $1873 \mathrm{~K}$ for $24 \mathrm{~h}$ and by crushing to a particle size of $1-9 \mu \mathrm{m}$ (average size: $3.1 \mu \mathrm{m}$ ). The formation of the compound $\mathrm{TiAl}_{2} \mathrm{O}_{5}$ was confirmed by X-ray diffraction. These powders were kept in a vacuum desiccator.

In the experiments conducted to examine the dissolution of $\mathrm{Ti}_{2} \mathrm{O}_{3}, \mathrm{CeO}_{2}, \mathrm{Ce}_{2} \mathrm{O}_{3}$, and $\mathrm{Al}_{2} \mathrm{O}_{3}$ in acid, the powders ( 5 $\mathrm{mg}$ ) were charged into $20 \mathrm{~mL}$ of $\mathrm{HCl}(1: 1)$ in a glass beaker and heated at around $363 \mathrm{~K}$ for 1 to $10 \mathrm{~h}$. After addition of $2 \mathrm{~mL}$ of $\mathrm{HNO}_{3}(1: 1)$, the beaker was again heated for 10 min. In the case of $\mathrm{ZrO}_{2}$, in order to prevent re-precipitation by hydrolysis of dissolved $\mathrm{Zr}$, the powder $(5 \mathrm{mg})$ was heated in $20 \mathrm{~mL}$ of $\mathrm{HCl}-\mathrm{HNO}_{3}-\mathrm{H}_{2} \mathrm{O}(1: 3: 4)$ at around $363 \mathrm{~K}$ for 1 to $10 \mathrm{~h}$. The acid was stirred at intervals of $30 \mathrm{~min}$. After an appropriate amount of time, $5 \mathrm{~mL}$ of the solution was suction-filtered using a film filter (open pore size: $0.1 \mu \mathrm{m}$ ) and analyzed by inductively coupled plasma-mass spectrometry (ICP-MS) or inductively coupled plasma-atomic emission spectrometry (ICP-AES).

In the experiment to examine the dissolution of powders in halogen-methanol or nonaqueous electrolytes, the powders $(5 \mathrm{mg})$ were charged into either $100 \mathrm{~mL}$ of $5 \mathrm{v} / \mathrm{v} \%$ bromine-methanol (316-333 $\mathrm{K}$ in an ultrasonic vibration bath), $14 \mathrm{w} / \mathrm{v} \%$ iodine-methanol $(316-333 \mathrm{~K}$ in an ultrasonic vibration bath), or nonaqueous electrolytes (room temperature). The preparation of a nonaqueous electrolyte composed of $2 \%$ TEA-Ba was described in a previous paper. ${ }^{13)}$ The electrolyte was stirred at intervals of $30 \mathrm{~min}$. After an appropriate amount of time, $5 \mathrm{~mL}$ of the solution was suction-filtered using a PTFE film filter (open pore size: 0.1 $\mu \mathrm{m})$ and analyzed by ICP-MS or ICP-AES.

\subsection{Metal Sample Preparation}

\section{1) $\mathrm{Fe}-\mathrm{Zr}$ alloy}

An appropriate amount of an $\mathrm{Fe}-50$ mass\% $\mathrm{Zr}$ alloy was added to $\mathrm{Fe}$ or an $\mathrm{Fe}-10$ mass\% Ni alloy melted in a $\mathrm{ZrO}_{2}-$ $11 \mathrm{~mol} \% \mathrm{CaO}$ crucible under a deoxidized $\mathrm{Ar}$ atmosphere at $1873 \mathrm{~K}$. The melt was stirred for $30 \mathrm{~s}$ using a $\mathrm{ZrO}_{2}-11$ $\mathrm{mol} \% \mathrm{CaO}$ tube and held at $1873 \mathrm{~K}$ for 1 to $2 \mathrm{~min}$. The crucible containing the metal sample was then rapidly quenched in water.

\section{2) $\mathrm{Fe}-\mathrm{Ti}$ alloy}

An appropriate amount of an Fe-50 mass\% Ti alloy was added to an $\mathrm{Fe}-10$ mass\% Ni alloy $(70 \mathrm{~g})$ in an $\mathrm{Al}_{2} \mathrm{O}_{3}$ crucible under a deoxidized $\mathrm{Ar}$ atmosphere at $1873 \mathrm{~K}$. The melt was then stirred for $20 \mathrm{~s}$ using an $\mathrm{Al}_{2} \mathrm{O}_{3}$ tube and held at $1873 \mathrm{~K}$ for 1 to $2 \mathrm{~min}$. The crucible containing the metal sample was rapidly quenched in water.

\section{3) $\mathrm{Fe}-\mathrm{Ce}$ alloy}

An appropriate amount of pure Ce granules was added to $\mathrm{Fe}-10$ mass $\% \mathrm{Ni}$ or $\mathrm{Fe}-0.2$ (or 0.1 ) mass $\% \mathrm{C}-0.02$ mass\% $\mathrm{P}$ alloys $(70 \mathrm{~g})$ in an $\mathrm{Al}_{2} \mathrm{O}_{3}$ crucible under a deoxidized $\mathrm{Ar}$ atmosphere at $1873 \mathrm{~K}$. The melt was then stirred for $20 \mathrm{~s}$ using an $\mathrm{Al}_{2} \mathrm{O}_{3}$ tube, held at $1873 \mathrm{~K}$ for $1 \mathrm{~min}$, and cooled to $1673 \mathrm{~K}$ at a cooling rate of $40 \mathrm{~K} / \mathrm{min}$. The crucible containing the metal sample was rapidly quenched in water. For a comparison, the crucible containing the metal sample was rapidly quenched in water after holding at $1873 \mathrm{~K}$ for $1 \mathrm{~min}$.

In the case of a base alloy (70 g) consisting of Fe-0.2 mass $\% \mathrm{C}-0.02$ mass $\% \mathrm{P}-0.008$ to 0.02 mass $\% \mathrm{~S}$, an appropriate amount of an $\mathrm{Fe}-10$ mass \% Al alloy was added for pre-deoxidation, and an appropriate amount of pure $\mathrm{Ce}$ granules was added to the base-alloy melt in an $\mathrm{Al}_{2} \mathrm{O}_{3}$ crucible under a deoxidized $\mathrm{Ar}$ atmosphere at $1873 \mathrm{~K}$. The melt was then stirred for $20 \mathrm{~s}$ using an $\mathrm{Al}_{2} \mathrm{O}_{3}$ tube and held at $1873 \mathrm{~K}$ for $1 \mathrm{~min}$. The crucible containing the metal sample was cooled to $1673 \mathrm{~K}$ at a cooling rate of $40 \mathrm{~K} / \mathrm{min}$, and rapidly quenched in water.

4) $\mathrm{Fe}-\mathrm{Al}$ alloy

An appropriate amount of an $\mathrm{Fe}-10$ mass\% $\mathrm{Al}$ alloy was added to pure $\mathrm{Fe}(70 \mathrm{~g})$ in an $\mathrm{Al}_{2} \mathrm{O}_{3}$ crucible under a deoxidized Ar atmosphere at $1873 \mathrm{~K}$. The melt was then stirred for $20 \mathrm{~s}$ using an $\mathrm{Al}_{2} \mathrm{O}_{3}$ tube, held at $1873 \mathrm{~K}$ for $2 \mathrm{~min}$, and cooled to $1673 \mathrm{~K}$ at a cooling rate of $40 \mathrm{~K} / \mathrm{min}$. The crucible containing the metal sample was rapidly quenched in water. 5) $\mathrm{Fe}-\mathrm{Mg}-\mathrm{Al}$ alloy

An appropriate amount of an $\mathrm{Fe}-10$ mass\% $\mathrm{Al}$ alloy and a Ni-10 mass\% $\mathrm{Mg}$ alloy was added to pure Fe (70 g) in a $\mathrm{MgO}$ crucible under a deoxidized Ar atmosphere at $1873 \mathrm{~K}$. The melt was then stirred for $20 \mathrm{~s}$ using an $\mathrm{Al}_{2} \mathrm{O}_{3}$ tube, held at $1873 \mathrm{~K}$ for $2 \mathrm{~min}$. The crucible containing the metal sample was rapidly quenched in water.

\subsection{Extraction and Estimation of Inclusion Particles}

Although the extraction procedure of inclusion particles from the metal sample was previously used in another study, ${ }^{13)}$ the mixed acid used for the extraction from Fe deoxidized by $\mathrm{Zr}$ and $\mathrm{Ti}$ was $\mathrm{HCl}-\mathrm{HNO}_{3}-\mathrm{H}_{2} \mathrm{O}(1: 3: 4)$ and $\mathrm{HCl}-$ $\mathrm{H}_{2} \mathrm{SO}_{4}-\mathrm{H}_{2} \mathrm{O}$ (4:1:5), respectively, to prevent re-precipitation by the hydrolysis of dissolved $\mathrm{Zr}$ and $\mathrm{Ti}$.

The procedures of observation, quantitative analysis of extracted inclusion particles and that of soluble elements in metal were also described in the previous paper, ${ }^{13)}$ along with that of observation of inclusion particles on the cross section of the metal sample.

The total $\mathrm{O}$ content of the metal was determined by inert gas fusion-infrared absorptiometry. ${ }^{15)}$ The total $\mathrm{S}$ content of the metal was determined by $\mathrm{O}_{2}$ gas fusion-infrared absorptiometry.

\section{Results and Discussion}

\subsection{Stability of $\mathrm{ZrO}_{2}$ Particles}

It was reported that only $\mathrm{ZrO}_{2}$ particles were extracted from steel by treating a steel sample sequentially with $\mathrm{HCl}$, $\mathrm{HF}$ and aqua regia ${ }^{16)}$ or $\mathrm{H}_{2} \mathrm{SO}_{4}, \mathrm{HF}$ and $\mathrm{HNO}_{3}{ }^{17)}$ Inclusion particles such as $\mathrm{ZrC}, \mathrm{ZrN}$, zirconium sulfide, and $\mathrm{ZrO}_{2}$ were extracted by dissolving the steel matrix with cold $\mathrm{HNO}_{3}{ }^{18,19)}$ During decomposition of the extracted $\mathrm{ZrC}$ by a mixed acid of $\left(\mathrm{H}_{2} \mathrm{O}_{2}+\mathrm{HF}\right)$ and $\left(\mathrm{HNO}_{3}+\mathrm{HF}\right), 12-23 \%$ of $\mathrm{ZrO}_{2}$ was dissolved in $1 \mathrm{~h}^{19)}$ It was considered that $\mathrm{ZrC}$ and $\mathrm{ZrS}_{2}$ dissolved, but $\mathrm{ZrN}$ and $\mathrm{ZrO}_{2}$ did not dissolve during the extraction with iodine-methanol. ${ }^{18,19)}$ Quantitative studies on $\mathrm{ZrO}_{2}$ dissolution loss using the previously suggested extraction methods have been insufficient.

In this study, the variation in the amount of dissolved $\mathrm{ZrO}_{2}$ reagent powder $(5 \mathrm{mg})$ in solution was examined using a $\mathrm{HCl}-\mathrm{HNO}_{3}-\mathrm{H}_{2} \mathrm{O}$ (1:3:4) mixed acid, iodine-methanol, 
and bromine-methanol. The results are shown in Fig. 1. The dissolution of $\mathrm{ZrO}_{2}$ powder was clearly seen in the mixed acid, while it was small in both kinds of halogen-methanol.

Citric acid is known as an organic compound that forms a stable, soluble, complex ion with $\mathrm{Zr}$ ion. A citric acidbased neutral electrolyte $(30 \mathrm{w} / \mathrm{v} \%$ citric acid-15 w/v\% sodium citrate- $1.2 \mathrm{w} / \mathrm{v} \% \mathrm{KBr}$ aqueous solution) was used for the extraction of $\mathrm{Zr}$-based inclusions from steel. ${ }^{19)}$ However, it might be suggested that since $\mathrm{Zr}$ ions are prone to hydrolysis, the use of aqueous electrolytes should be prevented, even if citric acid is present in high concentrations. The time dependence of the dissolution of $\mathrm{ZrO}_{2}$ reagent powder in $4 \% \mathrm{MS}, 2 \% \mathrm{TEA}, 10 \% \mathrm{AA}$, and $40 \% \mathrm{MA}$, which are nonaqueous organic electrolytes, are also shown in Fig. 1. It can be seen that the amount of dissolved $\mathrm{ZrO}_{2}$ reagent was small in these electrolytes. Since there was a possibility that pitting could form on the steel surface during electrolysis with $2 \% \mathrm{TEA}^{9}{ }^{9}$ the use of $4 \% \mathrm{MS}, 10 \% \mathrm{AA}$, and $40 \% \mathrm{MA}$ was preferred.

Because of the difference in morphology, size, and chemical stability between a reagent and actual inclusion particles, the extraction conditions obtained using a reagent or synthesized compounds were believed to be inapplicable to the actual extraction from metal. ${ }^{20,21)}$ The amount of $\mathrm{Al}_{2} \mathrm{O}_{3}$ dissolved in acid was varied depending on the $\mathrm{Al}_{2} \mathrm{O}_{3}$ crystal structure. ${ }^{22)}$ Therefore, the applicability of the $\mathrm{ZrO}_{2}$ extraction methods should be examined using an Fe sample deoxidized by an $\mathrm{Fe}-\mathrm{Zr}$ alloy in a deoxidized $\mathrm{Ar}$ atmosphere at $1873 \mathrm{~K}$.

$\mathrm{ZrO}_{2}$ inclusion particles in $\mathrm{Fe}-10$ mass $\% \mathrm{Ni}-0.06$ to 0.16 mass $\% \mathrm{Zr}$ alloys were extracted by a $\mathrm{HCl}-\mathrm{HNO}_{3}-\mathrm{H}_{2} \mathrm{O}$ (1:3:4) mixed acid, iodine-methanol, or the potentiostatic extraction method using $4 \% \mathrm{MS}, 10 \% \mathrm{AA}$, or $40 \% \mathrm{MA}$. The concentration of oxygen present as $\mathrm{ZrO}_{2}$ inclusion particles was calculated from the insoluble $\mathrm{Zr}$ content, [insol.Zr], obtained by each extraction method. On the other hand, it was possible to evaluate the oxygen content of $\mathrm{ZrO}_{2}$ inclusion particles by subtracting the equilibrium oxygen content, [sol.O] $]_{\text {eq. }}$, which was calculated by the equilibrium constant $K_{1}$ of Eq. (1) and the respective interaction parameters, ${ }^{23)}$ from the total oxygen content determined by inert gas fusion-infrared absorptiometry:

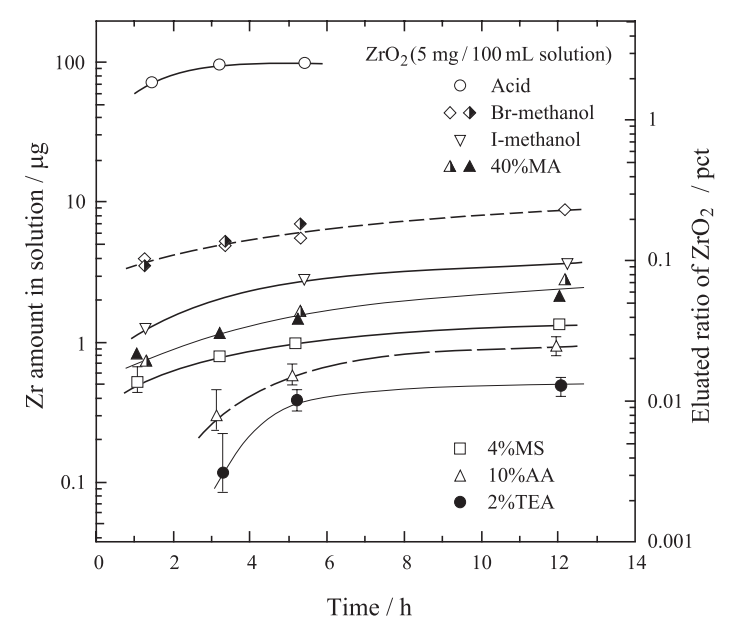

Fig. 1. Eluated ratio of $\mathrm{ZrO}_{2}$ in various solutions plotted against time.

$$
\begin{aligned}
& \mathrm{ZrO}_{2}(\mathrm{~s})=\underline{\mathrm{Zr}}+2 \underline{\mathrm{O}} \\
& \log K_{1}=-9.83(\text { at } 1873 \mathrm{~K})^{23)}
\end{aligned}
$$

where $i$ denotes the element $i$ dissolved in iron and its standard state is 1 mass \%. The oxygen content present as $\mathrm{ZrO}_{2}$ calculated from [insol.Zr] was plotted against those from the total oxygen content and [sol.O $]_{\text {eq. }}$ in Fig. 2. The results of the electrolytic method using the $4 \% \mathrm{MS}$ and $10 \% \mathrm{AA}$ electrolytes lie on the 1:1 line, while those using the $40 \% \mathrm{MA}$ electrolyte deviated slightly from the 1:1 line, suggesting that the electrolytic method using $4 \% \mathrm{MS}$ and $10 \% \mathrm{AA}$ electrolytes were effective for the extraction of $\mathrm{ZrO}_{2}$ inclusion particles. The experimental data points obtained with iodinemethanol might be considered to lie on the 1:1 line, although they were scattered. In contrast, the data points for the mixed acid were positioned away from the 1:1 line. For Fe0.0004 to 0.6 mass $\% \mathrm{Zr}$ and $\mathrm{Fe}-10$ mass $\% \mathrm{Ni}-0.06$ to 0.16 mass $\% \mathrm{Zr}$ alloys, the values of [insol. $\mathrm{Zr}$ ] obtained with the mixed acid, iodine-methanol and the electrolysis using $10 \%$ AA were compared with those by the electrolysis using $4 \% \mathrm{MS}$ in Fig. 3. The comparison showed that the iodine-

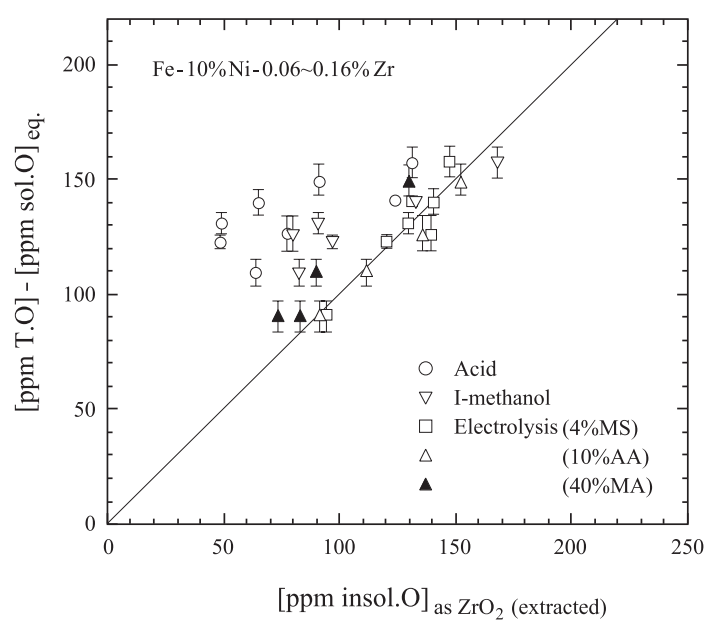

Fig. 2. Comparison of oxygen contents as $\mathrm{ZrO}_{2}$ inclusion obtained by total oxygen analysis with those calculated from extracted $\mathrm{ZrO}_{2}$.

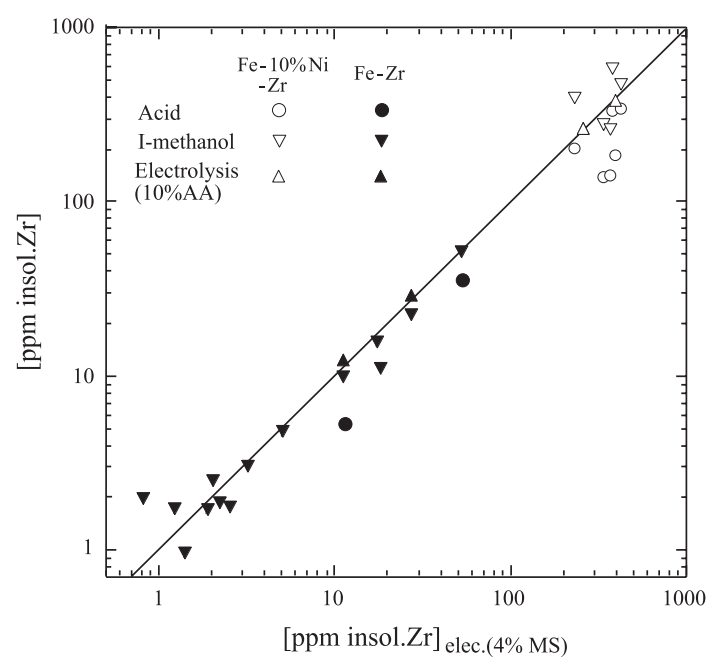

Fig. 3. Comparison of insoluble $\mathrm{Zr}$ contents extracted by acid, iodine-methanol and electrolysis using $10 \% \mathrm{AA}$ with those by electrolysis using $4 \% \mathrm{MS}$. 
methanol method could be applied to the extraction of $\mathrm{ZrO}_{2}$ inclusion particles; the experimental findings showed that [insol.Zr] obtained by this method corresponded well to those obtained by electrolysis.

\subsection{Stability of $\mathrm{Ti}_{2} \mathrm{O}_{3}$ Particles}

The Ti content in the $\mathrm{Fe}-10$ mass $\% \mathrm{Ni}$ alloy premelted in this study was $0.13-0.21$ mass $\%$. In this Ti concentration range, according to the previous findings using $\mathrm{X}$-ray diffraction, $\mathrm{Ti}_{2} \mathrm{O}_{3}{ }^{20,24)} \mathrm{Ti}_{3} \mathrm{O}_{5},{ }^{25-27)}$ and $\mathrm{TiO}_{2}{ }^{28)}$ were identified to be inclusions, and the coexistence of $\mathrm{Ti}_{2} \mathrm{O}_{3}$ and $\mathrm{TiO}$ or $\mathrm{Ti}_{2} \mathrm{O}_{3}$ and $\mathrm{Ti}_{3} \mathrm{O}_{5}$ was also reported. ${ }^{29)}$ When the relationships between the Ti content and oxygen activity were obtained by the electromotive-force method using a solid electrolyte, $\mathrm{Ti}_{2} \mathrm{O}_{3}{ }^{30)}$ and $\mathrm{Ti}_{3} \mathrm{O}_{5}{ }^{31)}$ were each shown as an equilibrium phase. From the thermodynamic calculation using standard free energies ${ }^{32}$ for the formation of $\mathrm{TiO}, \mathrm{Ti}_{2} \mathrm{O}_{3}, \mathrm{Ti}_{3} \mathrm{O}_{5}$, $\mathrm{Ti}_{4} \mathrm{O}_{7}$, and $\mathrm{TiO}_{2}$, the free energies for the dissolution of $\mathrm{Ti}(\mathrm{s})$ and $\mathrm{O}_{2}$ into liquid iron, ${ }^{33)}$ and the respective interaction parameters, $\left.{ }^{33}\right) \mathrm{Ti}_{2} \mathrm{O}_{3}$ and $\mathrm{Ti}_{3} \mathrm{O}_{5}$ were shown to be the most stable titanium oxide phases at $1873 \mathrm{~K}$ in the Ti concentration range of $0.13-0.21$ and $0.0003-0.13$ mass $\%$, respectively.

Kawamura et al. ${ }^{20)}$ reported that the synthesized $\mathrm{Ti}_{2} \mathrm{O}_{3}(7$ $\mathrm{mg}$ ) dissolved completely in hot $\mathrm{HCl}$ or hot $\mathrm{H}_{2} \mathrm{SO}_{4}$ solution after $20 \mathrm{~min}$, but remained undissolved in iodine--methanol and bromine-methanol at $70^{\circ} \mathrm{C}$ for $20 \mathrm{~min}$. However, a period of 20 minutes is too short to dissolve an considerable amount of iron sample. In order to clarify the stability of $\mathrm{Ti}_{2} \mathrm{O}_{3}$ in the solution, the dissolution of fine $\mathrm{Ti}_{2} \mathrm{O}_{3}$ powder, whose average grain size is $0.41 \mu \mathrm{m}$, was examined in halogen-methanol (316-333 $\mathrm{K}$ in ultrasonic vibration bath), $4 \% \mathrm{MS}, 10 \% \mathrm{AA}$, and $40 \% \mathrm{MA}$. The variation in the amount of $\mathrm{Ti}$ dissolved from fine $\mathrm{Ti}_{2} \mathrm{O}_{3}$ powder in these solutions with time is shown in Fig. 4. $\mathrm{Ti}_{2} \mathrm{O}_{3}$ powder was found to be stable in iodine-methanol, and is expected to be stable in bromine-methanol only for a short time. Since salicylic acid can form a stable complex ion with $\mathrm{Ti}$ ion, ${ }^{34)} 4 \% \mathrm{MS}$ is considered to be suitable as a nonaqueous electrolyte. The amount of dissolved $\mathrm{Ti}_{2} \mathrm{O}_{3}$ particles in both $4 \% \mathrm{MS}$ and $10 \% \mathrm{AA}$ and $40 \% \mathrm{MA}$ was small enough to be deemed negligible, as shown in Fig. 4.

The applicability of the $\mathrm{Ti}_{2} \mathrm{O}_{3}$ extraction methods was examined using $\mathrm{Fe}$ and $\mathrm{Fe}-10$ mass\% $\mathrm{Ni}$ samples deoxi-

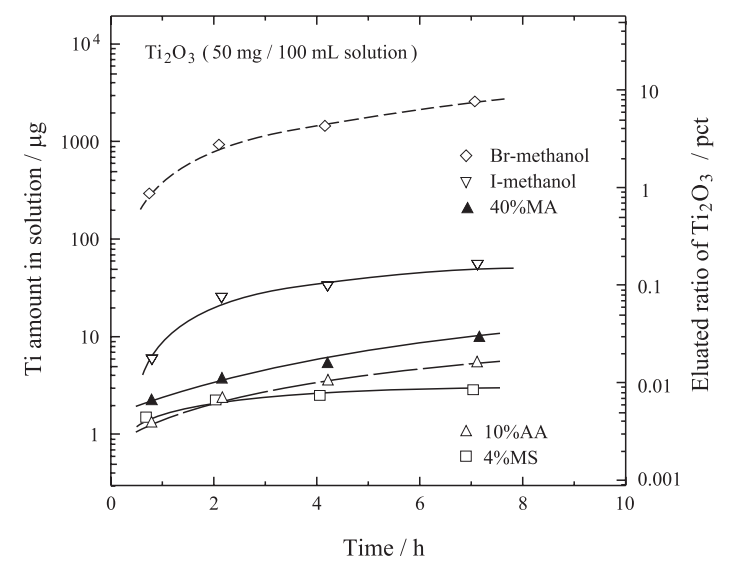

Fig. 4. Eluated ratio of $\mathrm{Ti}_{2} \mathrm{O}_{3}$ in various solutions plotted against time. dized by an Fe-Ti alloy in a deoxidized Ar atmosphere at $1873 \mathrm{~K}$. The oxygen content in the inclusion particles obtained by electrolytic extraction with $4 \% \mathrm{MS}$ and $40 \% \mathrm{MA}$ are plotted against those obtained by subtracting the equilibrium oxygen content, which was thermodynamically evaluated by using $\Delta G^{\circ}$ for the reaction in Eq. (2) and interaction parameters ${ }^{33)}$ from the analyzed total oxygen content in Fig. 5:

$$
\begin{aligned}
& \mathrm{Ti}_{2} \mathrm{O}_{3}(\mathrm{~s})=2 \underline{\mathrm{Ti}}+3 \underline{\mathrm{O}} \\
& \Delta G_{2}^{\circ}=1078000-351.2 T[\mathrm{~J} / \mathrm{mol}]^{32,33)}
\end{aligned}
$$

The validity of potentiostatic electrolysis was obvious because the results obtained by electrolytic extraction using $4 \% \mathrm{MS}$ and $40 \% \mathrm{MA}$ agreed well with the thermodynamically calculated values. However, the results obtained using the $\mathrm{HCl}-\mathrm{H}_{2} \mathrm{SO}_{4}-\mathrm{H}_{2} \mathrm{O}$ (4:1:5) solution and iodine-methanol deviated from the calculated values because of the dissolution of inclusion particles.

\subsection{Stability of $\mathrm{TiAl}_{2} \mathrm{O}_{5}$ Particles}

It was previously reported that the fine $\mathrm{Al}_{2} \mathrm{O}_{3}$ reagent was stable in halogen-methanol and nonaqueous electrolytes such as $2 \%$ TEA, $4 \% \mathrm{MS}$, and $10 \% \mathrm{AA}^{7)}$ The $\mathrm{TiAl}_{2} \mathrm{O}_{5}$ phase, which is a compound of $\mathrm{TiO}_{2}$ and $\mathrm{Al}_{2} \mathrm{O}_{3}$, was observed in the limited concentration ranges of $\mathrm{Al}$ and $\mathrm{Ti}$ in liquid iron. ${ }^{35)}$ The dissolution of synthesized $\mathrm{TiAl}_{2} \mathrm{O}_{5}$ fine powder with an average grain size of $3.1 \mu \mathrm{m}$ was examined in halogen-methanol (316-333 $\mathrm{K}$ in ultrasonic vibration bath), $4 \% \mathrm{MS}$, and $10 \% \mathrm{AA}$. Figure 6 shows the variation of $\mathrm{Ti}$ content in these solutions with time. The $\mathrm{TiAl}_{2} \mathrm{O}_{5}$ powder was found to be stable in both halogen-methanol and nonaqueous electrolytes, as is the case for $\mathrm{Al}_{2} \mathrm{O}_{3}$.

The extraction of $\mathrm{TiAl}_{2} \mathrm{O}_{5}$ from an $\mathrm{Fe}-\mathrm{Al}-\mathrm{Ti}$ alloy was not carried out in this study. When inclusion particles were extracted from $\mathrm{Fe}-0.11$ mass $\% \mathrm{Al}$ and $\mathrm{Fe}-0.01$ mass $\% \mathrm{Mg}-$ 0.05 mass $\% \mathrm{Al}$ alloys using the $40 \% \mathrm{MA}$ electrolyte, the suction filtration took a long time owing to the formation of gel in the electrolyte, and the $\mathrm{Al}_{2} \mathrm{O}_{3}$ inclusion content was higher than those using the 2\%TEA, 2\% TEA-0.16 mass $\%$

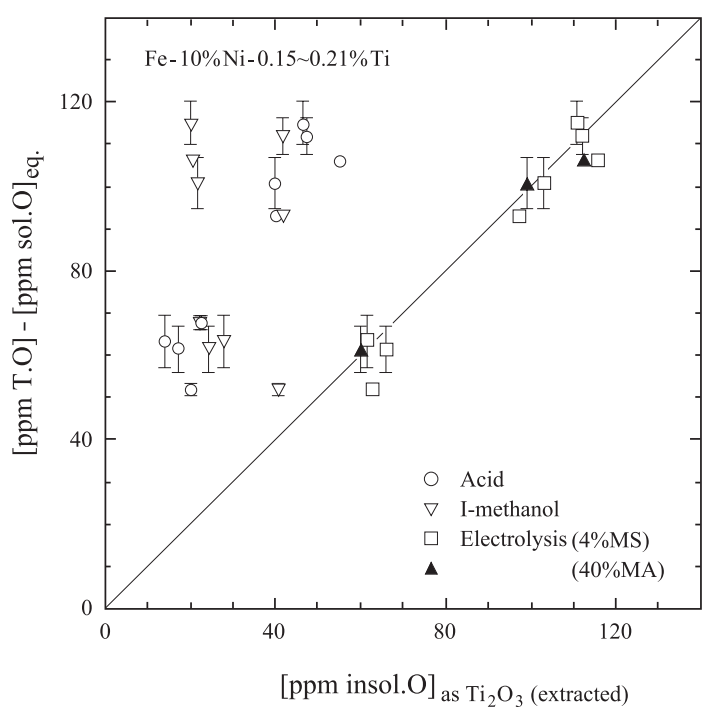

Fig. 5. Comparison of oxygen contents as $\mathrm{Ti}_{2} \mathrm{O}_{3}$ inclusion obtained by total oxygen analysis with those calculated from extracted $\mathrm{Ti}_{2} \mathrm{O}_{3}$. 


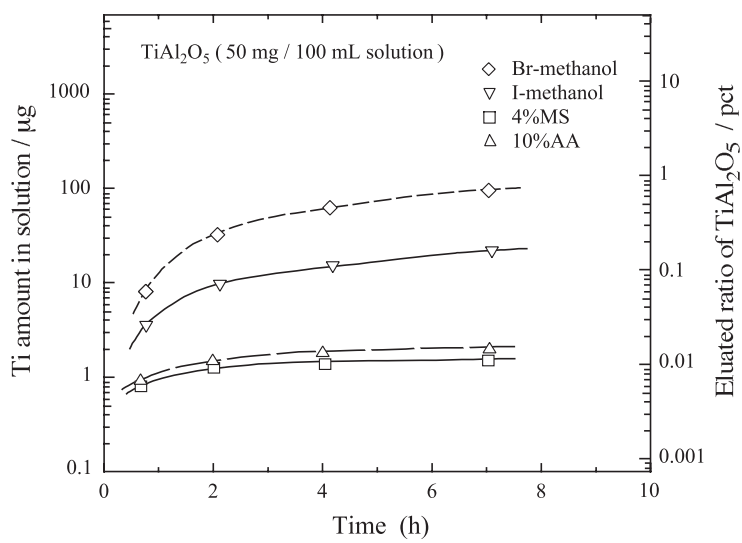

Fig. 6. Eluated ratio of $\mathrm{TiAl}_{2} \mathrm{O}_{5}$ in various solutions plotted against time.

Table 1. Contents of inclusion particles extracted from $\mathrm{Fe}-\mathrm{Al}$ and $\mathrm{Fe}-\mathrm{Mg}-\mathrm{Al}$ alloys.

\begin{tabular}{|c|c|c|c|}
\hline Metal & Electrolyte & $\begin{array}{l}\text { Insol.Al } \\
(\mathrm{ppm})\end{array}$ & $\begin{array}{c}\text { Insol.Mg } \\
\text { (ppm) }\end{array}$ \\
\hline \multirow{3}{*}{$\mathrm{Fe}-0.11$ mass $\% \mathrm{Al}$} & $2 \%$ TEA & 42,46 & - \\
\hline & $10 \% \mathrm{AA}$ & 40,46 & - \\
\hline & $40 \% \mathrm{MA}$ & 86,109 & - \\
\hline \multirow{4}{*}{$\begin{array}{c}\mathrm{Fe}-0.01 \mathrm{mass} \% \mathrm{Mg} \\
-0.05 \mathrm{mass} \% \mathrm{Al}\end{array}$} & $2 \%$ TEA & 27,29 & 49,50 \\
\hline & $\begin{array}{l}2 \% \text { TEA } \\
-0.16 \text { mass } \% \mathrm{Ba}\end{array}$ & 28,29 & 51,55 \\
\hline & $10 \% \mathrm{AA}$ & 27,28 & 45,48 \\
\hline & $40 \% \mathrm{MA}$ & $76,83,86$ & $37,41,43$ \\
\hline
\end{tabular}

$\mathrm{Ba}$ and $10 \% \mathrm{AA}$ electrolytes, as listed in Table 1. It is suggested that the precipitation of the gel proceeded in the $40 \% \mathrm{MA}$ electrolyte after the reaction between the $\mathrm{Al}$ ions, dissolved from the metal matrix containing a large amount of soluble Al, and the maleic acid. Therefore, it should be noted that the $40 \% \mathrm{MA}$ electrolyte could not be used for the extraction of $\mathrm{Al}_{2} \mathrm{O}_{3}$ and $\mathrm{TiAl}_{2} \mathrm{O}_{5}$ from an iron sample with high $\mathrm{Al}$ content.

\subsection{Stability of Ce Oxide and Ce Sulfide}

The dissolution behaviors of $\mathrm{Ce}$ oxide and Ce sulfide in a nonaqueous electrolyte were examined in the same manner as other oxides; $\mathrm{Ce}_{2} \mathrm{O}_{3}$ and $\mathrm{CeO}_{2}$ reagents were used as the $\mathrm{Ce}$ oxides while $\mathrm{Ce}_{2} \mathrm{~S}_{3}$ was used as the Ce sulfide.

Figure 7 shows the results for dissolution behaviors of $\mathrm{Ce}_{2} \mathrm{O}_{3}$ and $\mathrm{CeO}_{2}$ reagents in 2\%TEA, 4\%MS, 10\%AA, and $2 \%$ TEA- $0.16 \mathrm{w} / \mathrm{v} \% \mathrm{Ba}$. These two Ce oxides barely dissolved in $4 \% \mathrm{MS}$ and $2 \% \mathrm{TEA}-\mathrm{Ba}$. For comparison, the results of $14 \mathrm{w} / \mathrm{v} \%$ iodine-methanol and $5 \mathrm{v} / \mathrm{v} \%$ brominemethanol are also given in Fig. 8. The dissolution of $\mathrm{Ce}$ oxides was negligibly small in $14 \mathrm{w} / \mathrm{v} \%$ iodine-methanol. However, since it was reported that $\mathrm{Ce}$-iodine precipitates under oxidizing conditions, ${ }^{36}$ ) there was a possibility that the Ce ions, which dissolved from the metal matrix reacted with iodine and precipitated as Ce-iodine. Although the extraction operation using iodine-methanol is usually performed under an inert gas atmosphere, iodine-methanol might be unsuitable for the extraction of inclusion particles from metal containing Ce owing to safety concerns.

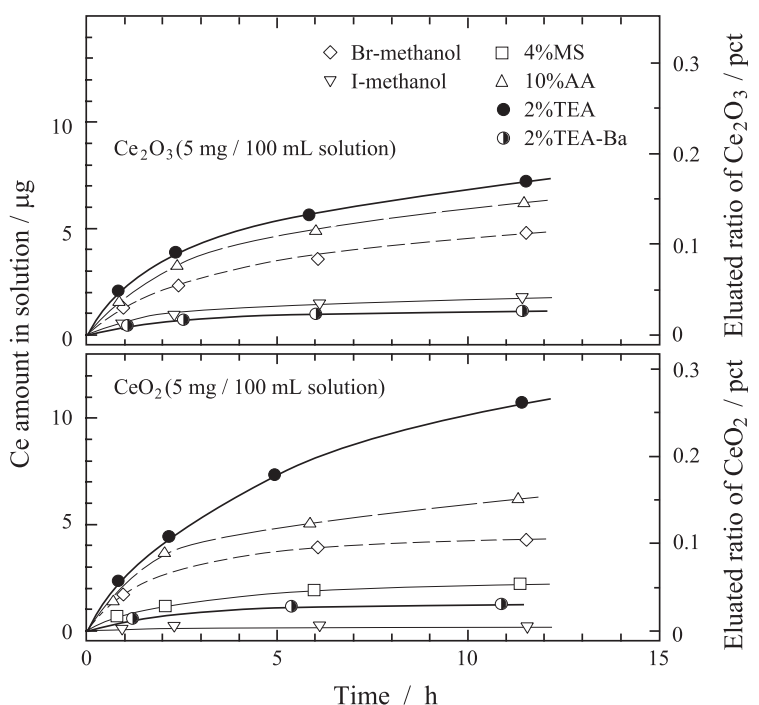

Fig. 7. Amount of $\mathrm{Ce}$ dissolved from $\mathrm{Ce}_{2} \mathrm{O}_{3}$ and $\mathrm{CeO}_{2}$ in various solutions plotted against time.

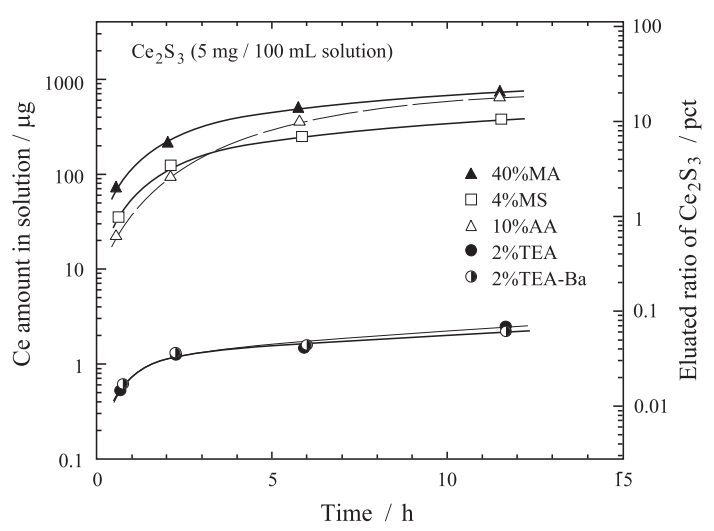

Fig. 8. Amount of $\mathrm{Ce}$ dissolved from $\mathrm{Ce}_{2} \mathrm{~S}_{3}$ in various solutions plotted against time.

The subcommittee on nonmetallic inclusion analysis at the Iron and Steel Institute of Japan had reported that 4\%MS is suitable for the electrolytic extraction of RE-sulfide. ${ }^{12)}$ The variation in $\mathrm{Ce}$ content dissolved from the $\mathrm{Ce}_{2} \mathrm{~S}_{3}$ reagent for various nonaqueous electrolytes is shown in Fig. 8 . The amounts of dissolved $\mathrm{Ce}_{2} \mathrm{~S}_{3}$ in $2 \%$ TEA and $2 \%$ TEA$0.16 \mathrm{w} / \mathrm{v} \% \mathrm{Ba}$ were smaller compared with that in $4 \% \mathrm{MS}$.

The potentiostatic electrolytic extraction of $\mathrm{Ce}_{2} \mathrm{O}_{3}$ from $\mathrm{Fe}-0.2 \mathrm{mass} \% \mathrm{C}-0.02$ mass $\% \mathrm{P}-0.02$ to 0.06 mass $\% \mathrm{Ce}$ and that of $\mathrm{CeS}$ from $\mathrm{Fe}-0.2$ mass $\% \mathrm{C}-0.02$ mass $\% \mathrm{P}-0.3$ mass $\%$ Al- 0.008 to 0.01 mass $\%$ S -0.03 to 0.05 mass $\% \mathrm{Ce}$ alloys were carried out using 2\%TEA-0.16 w/v\% Ba and $4 \% \mathrm{MS}$. The electrolytic potential was -100 to $-150 \mathrm{mV}$, and the current density was 15 to $35 \mathrm{~mA} / \mathrm{cm}^{2}$. The Ce concentrations in inclusions obtained by electrolytic extraction and acid treatment are listed in Table 2. It is seen that $\mathrm{Ce}_{2} \mathrm{O}_{3}$ and $\mathrm{CeS}$ dissolved drastically in $\mathrm{HCl}-\mathrm{HNO}_{3}-\mathrm{H}_{2} \mathrm{O}$ (3:1:4) mixed acid.

By electron-probe microanalysis, the inclusion particles on polished $\mathrm{Fe}-10$ mass $\% \mathrm{Ni}-0.04$ to 0.09 mass $\% \mathrm{Ce}$ and $\mathrm{Fe}-0.2$ mass $\% \mathrm{C}-0.02$ mass $\% \mathrm{P}-0.02$ to $0.10 \mathrm{mass} \% \mathrm{Ce}$ alloys were identified as nearly pure $\mathrm{Ce}_{2} \mathrm{O}_{3}$, and those on polished $\mathrm{Fe}-0.2$ mass\% $\mathrm{C}-0.02$ mass $\% \mathrm{P}-0.3$ mass\% $\mathrm{Al}-$ 0.008 to 0.02 mass $\% \mathrm{~S}-0.02$ to 0.08 mass $\%$ Ce alloys were 
Table 2. Comparison of contents of $\mathrm{Ce}_{2} \mathrm{O}_{3}$ or $\mathrm{CeS}$ inclusion particles extracted by various methods.

\begin{tabular}{|c|c|c|c|}
\hline \multirow{3}{*}{$\begin{array}{c}{[\mathrm{T} . \mathrm{Ce}]} \\
(\mathrm{ppm})\end{array}$} & \multicolumn{3}{|c|}{ Insol.Ce (ppm) } \\
\hline & \multicolumn{2}{|l|}{ Electrolysis } & \multirow{2}{*}{ Acid } \\
\hline & $2 \%$ TEA- 0.16 mass $\% \mathrm{Ba}$ & $4 \% \mathrm{MS}$ & \\
\hline \multicolumn{4}{|c|}{$\mathrm{Fe}-0.2$ mass $\%$ C- 0.02 mass $\% \mathrm{P}$} \\
\hline 236 & 210,219 & 160,167 & 1.3 \\
\hline 402 & 372,388 & 284 & $<0.1$ \\
\hline 592 & 555,567 & 394 & 1.4 \\
\hline \multicolumn{4}{|c|}{$\mathrm{Fe}-0.2$ mass $\%$ C -0.02 mass $\%$ P- 0.3 mass $\%$ Al- $0.008-0.01$ mass $\% \mathrm{~S}$} \\
\hline 298 & 301,313 & 215,230 & $<0.1$ \\
\hline 443 & 405 & 281 & $<0.1$ \\
\hline 499 & 450,485 & 370,423 & 2.3 \\
\hline
\end{tabular}

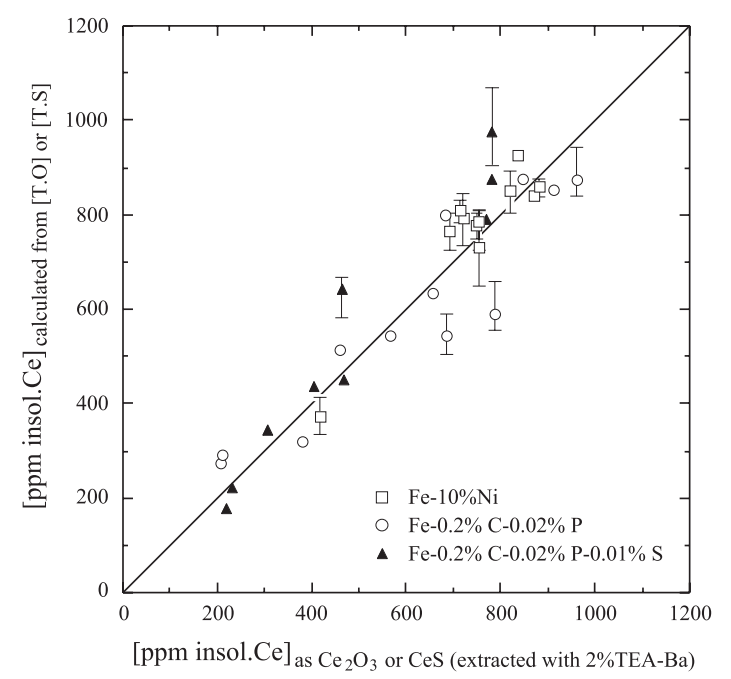

Fig. 9. Comparison of $\mathrm{Ce}$ contents as inclusion extracted by electrolytic method using 2\%TEA-Ba with those calculated from total $\mathrm{O}$ or total $\mathrm{S}$ content.

identified as nearly pure CeS. These alloys were obtained by quenching at $1673 \mathrm{~K}$ after cooling from $1873 \mathrm{~K}$ at a cooling rate of $40 \mathrm{~K} / \mathrm{min}$. Therefore, the $\mathrm{Ce}$ concentrations in $\mathrm{Ce}_{2} \mathrm{O}_{3}$ and $\mathrm{CeS}$ inclusion particles were calculated from the analyzed total $\mathrm{O}$ content and total $\mathrm{S}$ content, respectively. The results are shown in Fig. 9. These calculated values correspond approximately to the Ce concentrations of inclusions obtained by electrolytic extraction with $2 \%$ TEA- 0.16 to $0.42 \mathrm{w} / \mathrm{v} \% \mathrm{Ba}$ electrolyte. We believe that $\mathrm{O}$ and $\mathrm{S}$ precipitated as $\mathrm{Ce}_{2} \mathrm{O}_{3}$ and $\mathrm{CeS}$ during cooling of the metal from a molten state at $1873 \mathrm{~K}$ to $1673 \mathrm{~K}$, and a part of $\mathrm{Ce}_{2} \mathrm{O}_{3}$ and $\mathrm{CeS}$ dissolved in the $4 \% \mathrm{MS}$ electrolyte during electrolytic extraction.

On the other hand, since the $\mathrm{Fe}-10$ mass $\% \mathrm{Ni}-0.08$ to 0.19 mass \% Ce and $\mathrm{Fe}-0.1$ mass \% C-0.02 mass\% $\mathrm{P}-0.02$ to $0.11 \mathrm{mass} \% \mathrm{Ce}$ alloys were obtained by quenching in water after the deoxidation with pure Ce granules at $1873 \mathrm{~K}$, soluble $\mathrm{O}$ was expected to remain in these alloys. Therefore, the $\mathrm{Ce}$ content present as $\mathrm{Ce}_{2} \mathrm{O}_{3}$ inclusion particles was calculated from the $\mathrm{O}$ content obtained by subtracting the equilibrium $\mathrm{O}$ concentration from the analyzed total $\mathrm{O}$ content. The equilibrium $\mathrm{O}$ concentration was thermodynamically evaluated by using $\log K_{3}$ for the reaction $(3)^{37)}$ and interac-

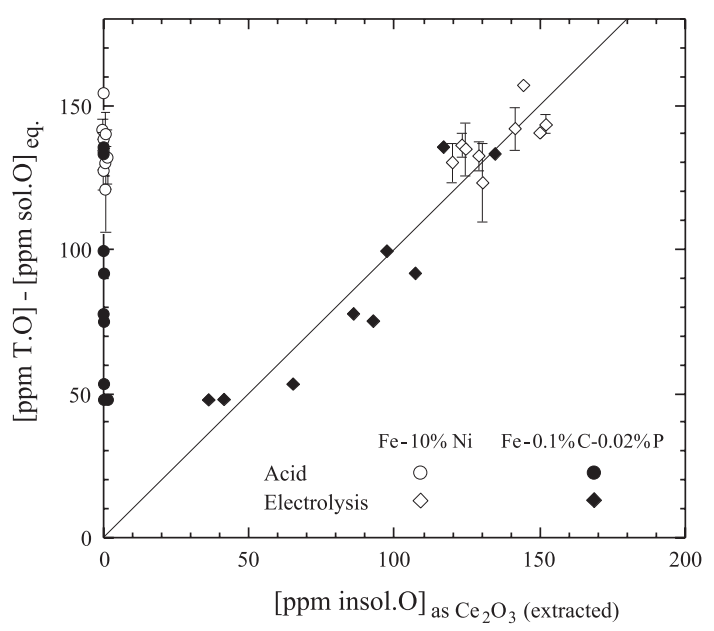

Fig. 10. Comparison of oxygen contents as $\mathrm{Ce}_{2} \mathrm{O}_{3}$ inclusion obtained by total oxygen analysis with those calculated from extracted $\mathrm{Ce}_{2} \mathrm{O}_{3}$.

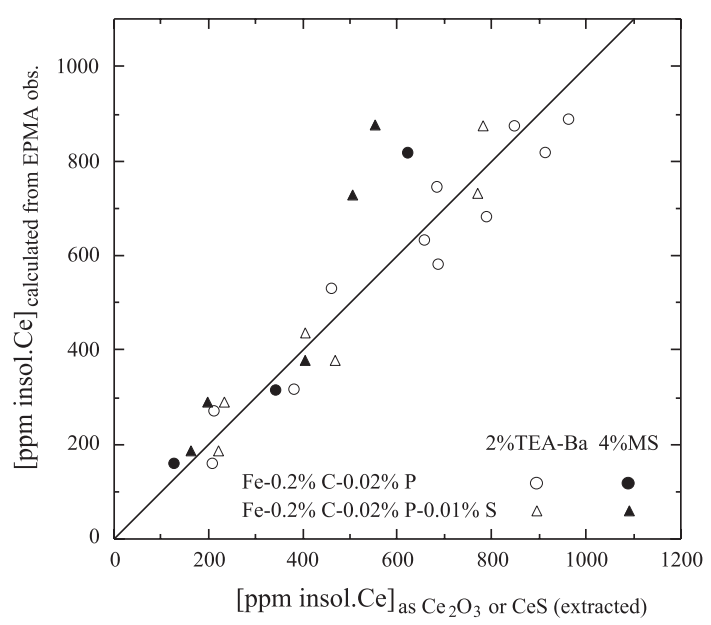

Fig. 11. Comparison of Ce contents as inclusion extracted by electrolytic method with those calculated from size and number of inclusion particles observed by EPMA.

tion parameters: ${ }^{33,37)}$

$$
\begin{aligned}
& \mathrm{Ce}_{2} \mathrm{O}_{3}(\mathrm{~s})=2 \underline{\mathrm{Ce}}+3 \underline{\mathrm{O}} \\
& \log K_{3}=-16.86(\text { at } 1873 \mathrm{~K})^{37)}
\end{aligned}
$$

Figure 10 shows the relationship between the calculated $\mathrm{Ce}$ content and the Ce content in inclusion particles extracted by the electrolytic method; the Ce concentrations in inclusion particles extracted with 2\%TEA-Ba electrolyte coincide substantially with the calculated values.

The inclusion amount was evaluated from the size and number of inclusion particles on cross sections of $\mathrm{Fe}-0.1$ mass \% C-0.02 mass\% $\%$-0.02 to 0.11 mass\% $\mathrm{Ce}$ and $\mathrm{Fe}-0.2$ mass $\% \mathrm{C}-0.02$ mass $\% \mathrm{P}-0.3$ mass $\% \mathrm{Al}-0.008$ to 0.02 mass \% S-0.02 to 0.08 mass\% Ce alloys. The calculation method was described in a previous paper. ${ }^{13)}$ The densities of $\mathrm{Ce}_{2} \mathrm{O}_{3}$ and $\mathrm{CeS}$ were $6.86 \mathrm{~g} / \mathrm{cm}^{3}$ and $5.88 \mathrm{~g} / \mathrm{cm}^{3}$, respectively. The calculated $\mathrm{Ce}$ content is plotted against the $\mathrm{Ce}$ content in extracted inclusion particles in Fig. 11. In the case of electrolytic extraction with $2 \%$ TEA- 0.25 to $0.42 \mathrm{w} / \mathrm{v} \%$ $\mathrm{Ba}$ electrolytes, both calculated and extracted values were in good agreement with each other, which might be explained by the homogeneous suspension of $\mathrm{Ce}_{2} \mathrm{O}_{3}$ and $\mathrm{CeS}$ in the 
molten alloy because the densities of $\mathrm{Ce}_{2} \mathrm{O}_{3}$ and $\mathrm{CeS}$ were close to that of molten iron $\left(6.9 \mathrm{~g} / \mathrm{cm}^{3}\right)$. Meanwhile, the extracted $\mathrm{Ce}$ concentrations in inclusion particles extracted by $4 \% \mathrm{MS}$ were consistent with both the calculated values and the values by $2 \%$ TEA- $-0.37 \mathrm{w} / \mathrm{v} \% \mathrm{Ba}$ in the low $\mathrm{Ce}-$ concentration range, but were lower than the calculated values in the higher $\mathrm{Ce}$-concentration range. This experimental finding means that $\mathrm{Ce}_{2} \mathrm{O}_{3}$ and $\mathrm{CeS}$ inclusion particles might dissolve in $4 \% \mathrm{MS}$.

\section{Conclusion}

Extraction methods using acid and halogen-methanol as well as electrolytic extraction employing various nonaqueous electrolytes were examined to separate nonmetallic inclusion particles from a steel sample without dissolution loss. For $\mathrm{ZrO}_{2}, \mathrm{Ti}_{2} \mathrm{O}_{3}$, and $\mathrm{TiAl}_{2} \mathrm{O}_{5}$ inclusion particles, electrolytic extraction using $4 \% \mathrm{MS}$ and $10 \% \mathrm{AA}$ electrolytes was successful, while the 2\%TEA-Ba electrolyte was favorable for potentiostatic extraction of $\mathrm{Ce}_{2} \mathrm{O}_{3}$ and $\mathrm{CeS}$ particles. It was concluded that judicious choice of the electrolyte based on the inclusion composition is essential.

\section{REFERENCES}

1) S. Maekawa: Tetsu-to-Hagané, 55 (1969), 381.

2) Y. Kawai, Y. Ishibashi, J. Chino and T. Kutsumi: Recent Development of Research on Nonmetallic Inclusions in Steel, ed. by Research Committee on Nonmetallic Inclusions in Steel, Japan Society for the Promotion of Science, Tokyo, (1994), 206.

3) J. Takamura and S. Mizoguchi: The 6th Int. Iron and Steel Cong., ISIJ, Tokyo, (1990), 591

4) M. Wako, T. Sawai and S. Mizoguchi: Tetsu-to-Hagané, 78 (1992), 1697.

5) S. Ogibayashi: Shinnittetsu-giho, 32 (1994), No. 351, 64.

6) A. Kojima, A. Kiyose, R. Uemori, M. Minagawa, M. Hoshino, T. Nakashima, K. Ishida and H. Yasui: Shinnittetsu-giho, 42 (2004), No. 380,2 .
7) R. Inoue, T. Ariyama and H. Suito: Asia Steel Int. Conf. 2009, The Korean Institute of Metals and Materials, Seoul, (2009), S11-16, 1.

8) R. Inoue, K. Kiyokawa, K. Tomoda, S. Ueda and T. Ariyama: 8th Int. Workshop on Progress in Analytical Chemistry \& Materials Characterization in the Steel and Metals Industries (CETAS 2011), Centre for Research in Metallurgy, Belgium, (2011), 118.

9) Y. Yoshida, Y. Funahashi, K. I and Y. Kamino: Kawatetsu-giho, 12 (1980), 653.

10) F. Kurosawa, I. Taguchi and R. Matsumoto: J. Jpn. Inst. Met., 44 (1980), 1288.

11) K. Narita: Tetsu-to-Hagané, 66 (1980), 2119

12) K. Narita: Tetsu-to-Hagané, 73 (1987), 67.

13) R. Inoue, T. Ariyama and H. Suito: ISIJ Int., 51 (2011), 2050.

14) A. Chino, S. Kinoshiro and T. Ono: Tetsu-to-Hagané, 93 (2007), 105.

15) R. Inoue and H. Suito: Mater. Trans. JIM, 31 (1991), 1164.

16) A. Adachi and K. Mizukawa: Tetsu-to-Hagané, 48 (1962), 683.

17) K. Narita, A. Tomita and S. Nachi: Tetsu-to-Hagané, 48 (1962), 1526.

18) K. Kawamura, S. Watanabe and S. Suzuki: Tetsu-to-Hagané, 58 (1972), 2067.

19) K. Kawamura, S. Watanabe, M. Amano, T. Uchida and S. Suzuki: Tetsu-to-Hagané, 61 (1975), 2650.

20) K. Kawamura, S. Watanabe and T. Uchida: Tetsu-to-Hagané, 57 (1971), 94.

21) S. Wakamatsu: Tetsu-to-Hagané, 57 (1971), 656.

22) F. Honda and K. Hirokawa: Tetsu-to-Hagané, 60 (1974), 2013

$23)$ R. Inoue, T. Ariyama and H. Suito: ISIJ Int., 48 (2008), 1175.

24) H. Straube, G. Kuhnelt and E. Plockinger: Arch. Eisenhüttenwes., 32 (1967), 607.

25) H. Chino, Y. Nakamura, E. Tsunetomi and K. Segawa: Tetsu-toHagané, 52 (1966), 959.

26) Y. Kojima, M. Inouye and J. Ohi: Arch. Eisenhüttenwes., 40 (1969), 667.

27) A. M. Smellie and H. B. Bell: Can. Metall. Q., 11 (1972), 351.

28) R. L. Hadley and G. Derge: Trans. Met. Soc. AIME, 203 (1955), 55.

29) E. L. Evans and H. A. Sloman: J. Iron Steel Inst., 174 (1953), 318.

30) D. Janke and W. A. Fischer: Arch. Eisenhüttenwes., 47 (1976), 195.

31) V. I. Yavoyskiy, L. P. Vladimirov, V. P. Luzgin, N. M. Kopitsa and E. B. Teplitskiy: Russ. Metall., (1974) No. 2, 10.

32) I. Barin: Thermochemical Data of Pure Substances, VCH, Weinheim, (1989).

33) G. K. Sigworth and J. F. Elliott: Met. Sci., 8 (1974), 298.

34) K. Ueno: Chelatometric Titration, Nankodo, Tokyo, (1972).

35) W. Choi, H. Matsuura and F. Tsukihashi: ISIJ Int., 51 (2011), 1951.

36) R. C. Vickery: Analytical Chemistry of the Rare Earths, Pergamon Press, New York, (1961), 35.

37) R. Inoue and H. Suito: CAMP-ISIJ, 10 (1997), 215. 